\title{
INFLUENCE OF OPAQUE PHOTOVOLTAIC SHADING ON MICROCLIMATE AND GROWTH OF STRAWBERRY IN GREENHOUSES
}

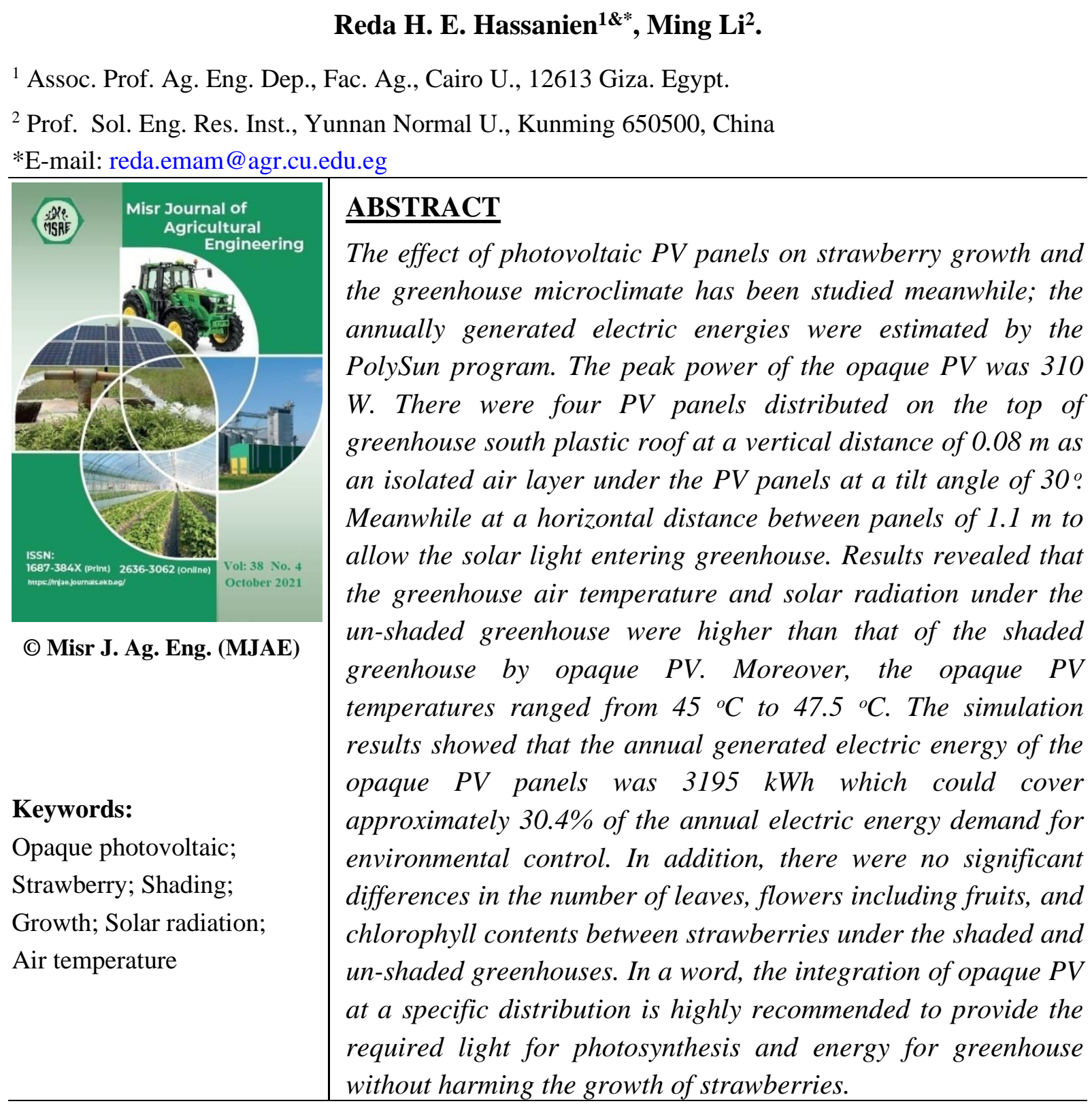

\section{INTRODUCTION}

A number of studies have been conducted to maximize the production of food and energy from the same agricultural area by integrating the photovoltaic panels on greenhouses roof (Cossu et al., 2014; Kadowaki et al., 2012; Yano et al., 2009; Yano et al., 2010). In addition, Li et al. (2017) reported that the payback period of the integrated photovoltaic and agricultural greenhouses in China was ranged from 4-8 years and the annual return was varied from $9 \%$ to $20 \%$. It was also observed that the PV integration with cropland could reduce the water consumption in both greenhouses and open filed irrigation (Marrou et al., 2013; Thotakura et al., 2020). Meanwhile, reduce part of the 
electrical energy for greenhouses operation (Hassanien et al., 2016; Hassanien et al., 2018b; Raúl, 2012) and decrease the gas emission of greenhouses (Breyer et al., 2015). However, it was reported that the integration of a straight-line (PVs) array on greenhouse decreased the fresh and dry-matter weights of welsh onions as well as decreased the annual yield by $25 \%$ compared to the checkerboard (PVc) and control due to its shading effect (Kadowaki et al., 2012).Stand-alone $P V$ power systems are very useful in remote and desert areas where commercial power grids are not available (Sivakumar and Jifon, 2018). Thereby, the integration of PV and greenhouses could provide most or part of the greenhouse electric energy demand. It was observed that most of the previous studies (Al-Ibrahim, 2006; AlShamiry, 2007; Sivakumar and Jifon, 2018; Sonneveld et al., 2010; Trypanagnostopoulos et al., 2017; Yano et al., 2014) used conventional opaque PV or planar flexible PV modules and directly integrated them above the roof or under the roof of greenhouses. Moreover, the integration of building integrated photovoltaic panels BIPV on greenhouses roof has been investigated and results revealed that BIPV had a non-significant effect on the growth and yield of lettuce and tomato plants in greenhouses (Reca et al., 2016; Thotakura et al., 2020). Furthermore, Al-Rousan et al. (2018) investigated the effect of a flexible photovoltaic panels on the microclimate and the yield of tomatoes during the summer and winter seasons, which mounted on the roof of greenhouse at area of $40 \%$ as checkerboard format in the south Mediterranean region. Results showed that the photovoltaic panels had no significant effect on microclimate and yield of tomatoes. It was reported that using the flexible, roll-to-roll printed, semi-transparent organic photovoltaics as a seasonal shade element for greenhouse production in a high-light region is feasible and did not influence the yield and growth of tomato (Waller et al., 2021).

Strawberry has a high content of essential nutrients, unique flavor and beneficial phytochemicals (Giampieri et al., 2012).It can be grown in greenhouses at optimal growth conditions of light, water, $\mathrm{CO}_{2}$, temperature, and nutrients in many regions of the world for a high-quality strawberries (Khanlari et al., 2020). The strawberry responds negatively to high temperature stress (Ghoulem et al., 2019). Due to, temperatures above $30{ }^{\circ} \mathrm{C}$ reduce fruit set and fruit size (Rylski and Spigelman, 1986).Moreover, it was found that strawberry plants exposed to high temperatures had lower fresh weight and smaller size of fruits compared to plants grown at low temperatures (Ledesma and Kawabata, 2016). It was noted that the low sunlight conditions caused by abnormal climate leads to a reduction in crop due to the depression of photosynthesis (Reca et al., 2016). Consequently, researchers have done a numerous experiment focusing on the effects of light and temperatures on strawberry growth. However, no more data are available about the growth of strawberry under shading effects of photovoltaic panels (PV) and how to overcome the shading effect by using the generated energy to operate the LED light. It was observed that shading the agricultural greenhouses along with pad and fan cooling system reduced greenhouse air temperatures below the ambient temperatures by $5-10{ }^{\circ} \mathrm{C}$. Moreover, reduced the solar radiation by $30-50 \%$ and decreased the energy consumption for cooling by $20 \%$ (Ahemd et al., 2016).

Thus, in the current study the opaque Poly-crystalline silicon PV panels were distributed at the south roof to investigate the effect on the growth of strawberry plants. Moreover, the 
annual electric energy production was investigated to figure out how much electric energy will be provided to assist the cooling and heating systems all the year around.

\section{MATERIALS AND METHODS}

\subsection{Greenhouses and photovoltaics (PV) characteristics}

This experiment has been implemented in Kunming, China (longitude $102.68^{\circ} \mathrm{E}$ and latitude $25.07^{\circ} \mathrm{N}$ ), in twins greenhouses of a single stand-alone structure with an equal gable roof in east-west orientation. The greenhouse dimensions were $(7.5 \mathrm{~m}$ length, $3.5 \mathrm{~m}$ wide, and $3 \mathrm{~m}$ height) in the middle and gutter height of $2 \mathrm{~m}$ at a roof slope of $30^{\circ}$. The greenhouses cover material was a Polyethylene (PE) film of $0.12 \mathrm{~mm}$ with light transmittance of $80 \%$. The natural ventilation was provided by vents along the side walls $(7 \mathrm{~m} \times 1 \mathrm{~m})$ with net curtains of white saran. The first greenhouse was as a control. Whereas, the second greenhouse was covered by opaque PV panels at a roof cover area of $25.9 \%$. Four opaque Poly-crystalline silicon of PV panels (peak power of $310 \mathrm{Wp}$ and module size of (1956 x 992 x $40 \mathrm{~mm}$ ) were distributed at $1.1 \mathrm{~m}$ interval spaces at the greenhouse roof area. All PV panels settled on top of the plastic cover at a tilt angle of $30^{\circ}$ and a vertical distance of $0.08 \mathrm{~m}$ as an isolated air channel between the plastic cover and the PV panels to reduce the heat stress and to avoid the high internal air temperatures and relative humidity from the greenhouse to the modules as well as from the solar panels to the greenhouse. The integration of opaque PV panels on greenhouses were as shown in Figure1 and the specifications of PVs are as shown in Table 1.
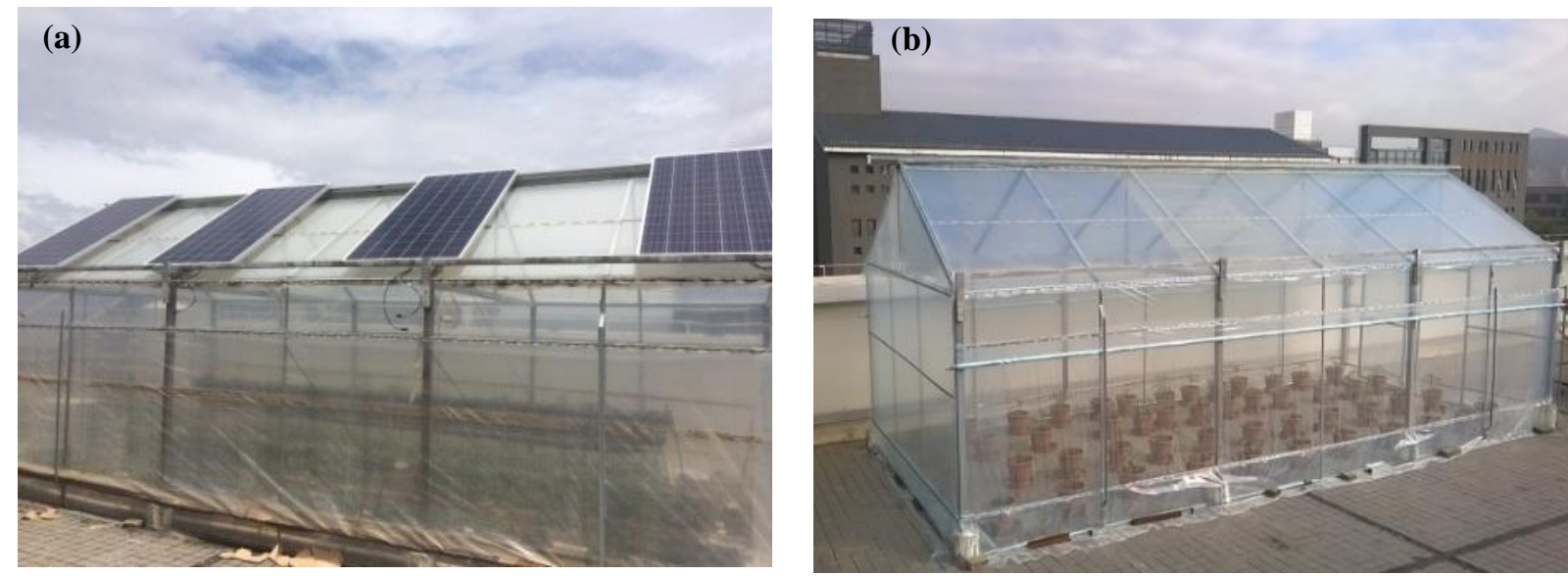

Figure 1: Greenhouse with opaque PV panels. (B) Greenhouse without PV panels

Table 1 Specifications of opaque photovoltaic module

\begin{tabular}{ll}
\hline Model & SA310-72P \\
Standard power & $310 \mathrm{~W}$ \\
Max.power voltage & $38.2 \mathrm{~V}$ \\
Max. power current & $8.1 \mathrm{~A}$ \\
Open circuit voltage & $45.8 \mathrm{~V}$ \\
Short circuit current & $8.9 \mathrm{~A}$ \\
Max system voltage & DC $1000 \mathrm{~V}$ \\
Size of module & $1956 * 992 * 40 \mathrm{~mm}$ \\
Module efficiency & $16 \%$ \\
Weight per piece $(\mathrm{kg})$ & $23.5 \mathrm{~kg}$ \\
\hline
\end{tabular}


The annual generated energies were estimated by using the PolySun program in Kunming, China. Light intensity was measured at heights of $0.5 \mathrm{~m}, 1 \mathrm{~m}$, and $2 \mathrm{~m}$, above the bases of Plants using a digital lux-meter. The environmental control parameters such as air temperature, solar radiation, and relative humidity were measured both outside and inside greenhouses. The PolySun program was used to simulate and predict the annual generated energy at different angles and covering area of the greenhouse roof. The tilt angle was chosen to be $30^{\circ}$ for the opaque PV to fit the length of panels with the greenhouse structure.

\subsection{Microclimate monitoring}

Mean daily relative humidity, light intensity, solar radiation, and air temperature were measured. Relative humidity was recorded each 30 minutes by an Accurate TH12R-EX recorder from Xin yada instrument Co., Ltd. made in China.

The light intensity was measured by a digital portable lux-meter from Taiwan, Tai Pei TES electronic industry. Ltd., China. The solar radiation at crop level was measured each minute in each treatment with pyranometer connected to a data logger (model TRM-2, Beijing Tianyu technology, Ltd., China).

Table 2. The specification of sensors and instruments

\begin{tabular}{lll}
\hline instrument name & Measurement range & Accuracy \\
\hline Thermocouple & $0-150^{\circ} \mathrm{C}$ & $\pm 0.1^{\circ} \mathrm{C}$ \\
Pyranometers & $0-2000 \mathrm{~W} / \mathrm{m} 2$ & $\pm 2 \%$ \\
Wind speed sensor & $0-70 \mathrm{~m} / \mathrm{s}$ & $0.5 \mathrm{~m} / \mathrm{s}$ \\
Digital portable lux meter & $(0-200000 \mathrm{~lx})$. & $\pm 11 \mathrm{x}$ \\
Accurate TH12R-EX & $0-100 \%$ & $\pm 0.2^{\circ} \mathrm{C}$ and $\pm 2 \%$ \\
\hline
\end{tabular}

Two sensors for solar radiation were installed at the level of plants and fixed in the un-shaded greenhouse and the shaded of opaque PV at the same height. Two sensors for air temperatures were distributed in each greenhouse at $1.0 \mathrm{~m}$ and $1.5 \mathrm{~m}$ above the ground level. Light intensity was measured at heights of $0.5 \mathrm{~m}, 1 \mathrm{~m}$, and $2 \mathrm{~m}$, above the bases of Plants using a digital lux-meter. The specifications of all sensors are shown in Table 2 and the monthly averaged weather variables in Kunming were obtained from NASA website (Paul W. Stackhouse, 2015 )

\subsection{Strawberry measurements}

Strawberry seedlings Fragaria ananassa (Jing Zang Xiang) were transplanted in pots at plant spacing in each row of $0.5 \mathrm{~m}$ and distance between rows of $0.5 \mathrm{~m}$. There were 91 pots for each greenhouse, each pot housing one plant. All plants had the same soil, irrigation and fertilization systems. There were two treatments (opaque PV and control greenhouses). The plant measurements were number of leaves, leaves area, number of flowers including fruits chlorophyll contents. The relative chlorophyll concentration of the leaves was measured by a portable chlorophyll meter (SPAD meter) measuring range: 0.0 99.9 SPAD,-10 99. $9^{\circ} \mathrm{C}$, 
aaccuracy: \pm 3.0 SPAD and leaf area by a portable leaf area meter Accuracy: $\pm 2 \%$, measuring range length: $\leq 1000 \mathrm{~mm}$, width: $\leq 160 \mathrm{~mm}$, thickness: $\leq 8 \mathrm{~mm}$, both instruments from Shanghai Rong Yan instruments. Co., Ltd, China. The strawberry experimental data were analyzed by the statistical software SPSS 18.0 (SPSS Inc., Chicago, IL, USA) by using the independent two-sample Student t-test at a $p$-value of 0.05 .

\section{RESULTS AND DISCUSSION}

\subsection{The effect of PV panels on the greenhouse microclimate}

\subsubsection{Air temperature}

Results revealed that the variation of temperature increases during daytime and decreases at night. It was observed that the greenhouse internal air temperature which covered by the opaque PV was lower than that of the un-shaded greenhouse during the daytime in the range of $1{ }^{\circ} \mathrm{C}$ to $2.5^{\circ} \mathrm{C}$ as shown in Figure 2, due to the opaque PV was distributed in a distance of $1.1 \mathrm{~m}$ on the greenhouse roof and the average temperature of shaded greenhouse was lower than the average temperature under the un-shaded greenhouse. In addition, the internal greenhouses temperatures were higher than the ambient temperatures by $5{ }^{\circ} \mathrm{C}-13{ }^{\circ} \mathrm{C}$ from 10 a.m. to 3 p.m.

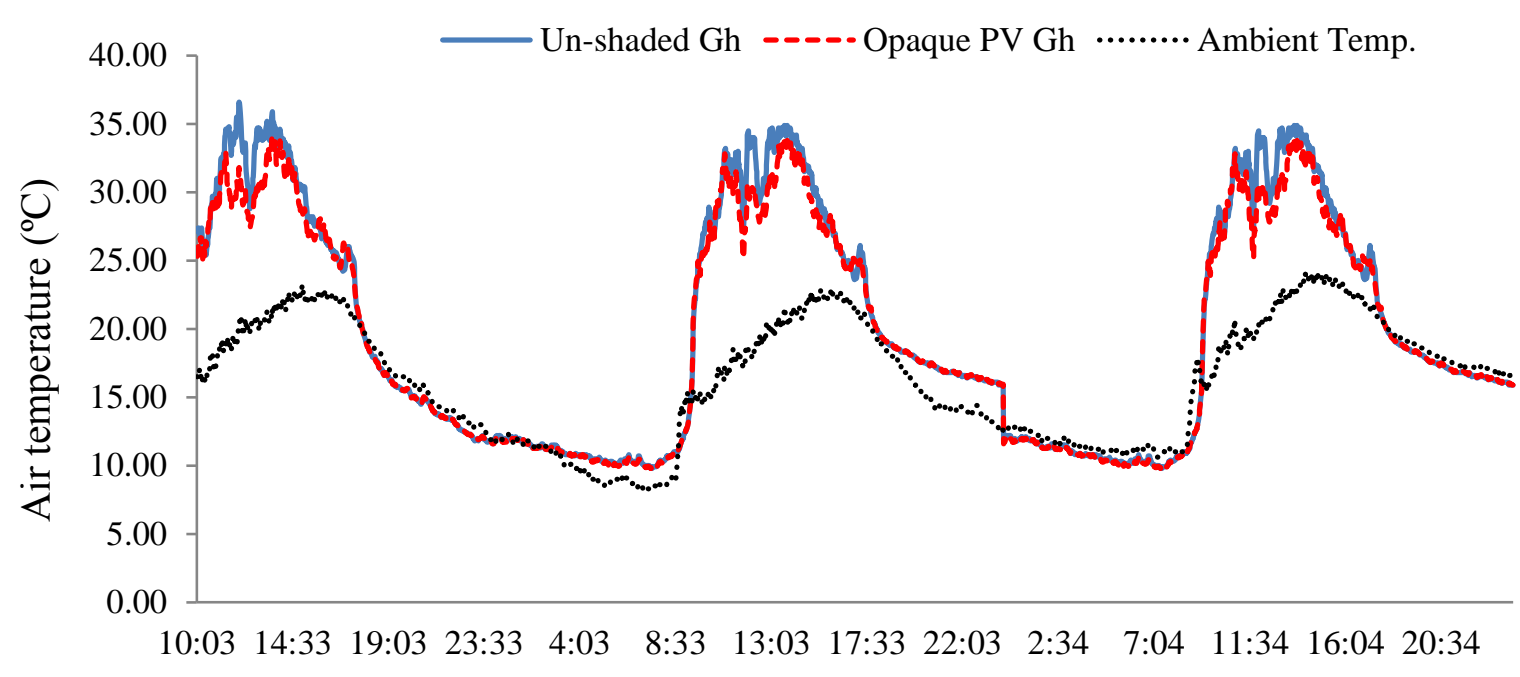

Time (h)

Figure 2: The internal greenhouse air temperature under opaque PV from $14^{\text {th }}$ to $16^{\text {th }}$ November, 2017

\subsubsection{Solar radiation}

The solar radiation under the opaque PV was lower than that of the un-shaded greenhouse as shown in Figure3. However, the variation was not high due to the opaque PVs were distributed on the roof of the greenhouse at a distance of $1.1 \mathrm{~m}$ from each other, which allow more solar radiation at the level of the plants. There was no observed variation of solar radiation on the cloudy days between the shaded and un-shaded greenhouses. The Peak values of solar radiation on clear and sunny days were high outside the greenhouse at the range of $\left(0.5-1.25 \mathrm{kWm}^{-2}\right)$. Meanwhile, solar radiation inside the control greenhouse was at the range of $\left(0.4-0.900 \mathrm{~kW} \mathrm{~m}^{-2}\right)$ and it was low under the polyethylene with opaque $\mathrm{PV}$ at the range of $\left(0.20-0.75 \mathrm{~kW} \mathrm{~m}^{-2}\right)$ 


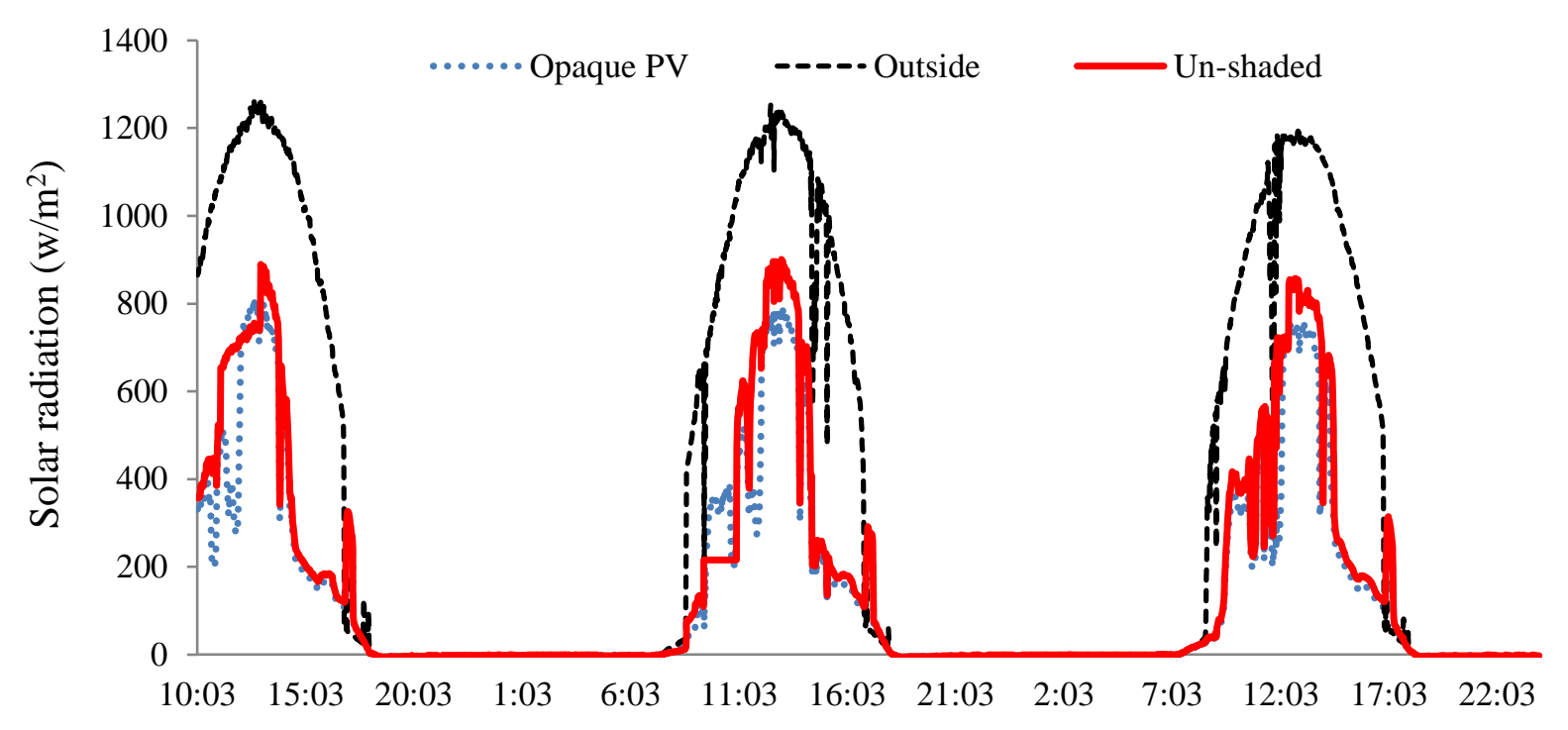

Time (h) November 14-16 sunny days at $0.5 \mathrm{~m}$ from the ground

Figure 3: The solar radiation under opaque PV on sunny days $\left(14^{\text {th }}\right.$ to $16^{\text {th }}$ November,2017).

Results of Figure 4 showed that the light intensity decreased from $2 \mathrm{~m}$ to $0.5 \mathrm{~m}$ under the shading of PV panels. The reduction under the plastic cover of the shaded greenhouses by opaque PV at $0.5 \mathrm{~m}$ to $2 \mathrm{~m}$ was ranged from 60 to $13 \%$, while, under the plastic cover of the un-shaded greenhouse was ranged from 86 to $64 \%$. The average light intensity outside the greenhouses was $85.6 \mathrm{klx}$ on a sunny day of November. While under the polyethylene cover it was $54.8 \mathrm{klx}$ at $0.5 \mathrm{~m}$ from the ground and $63 \mathrm{klx}$ at $1.5 \mathrm{~m}$ and $73.5 \mathrm{klx}$ at $2 \mathrm{~m}$ from the ground. Meanwhile, the light intensity under the shaded greenhouse by PV was $53.5 \mathrm{klx}$ at 0.5 $\mathrm{m}$ from the ground, $15 \mathrm{klx}$ at $1.5 \mathrm{~m}$ and $11 \mathrm{klx}$ at $2 \mathrm{~m}$ from the ground.

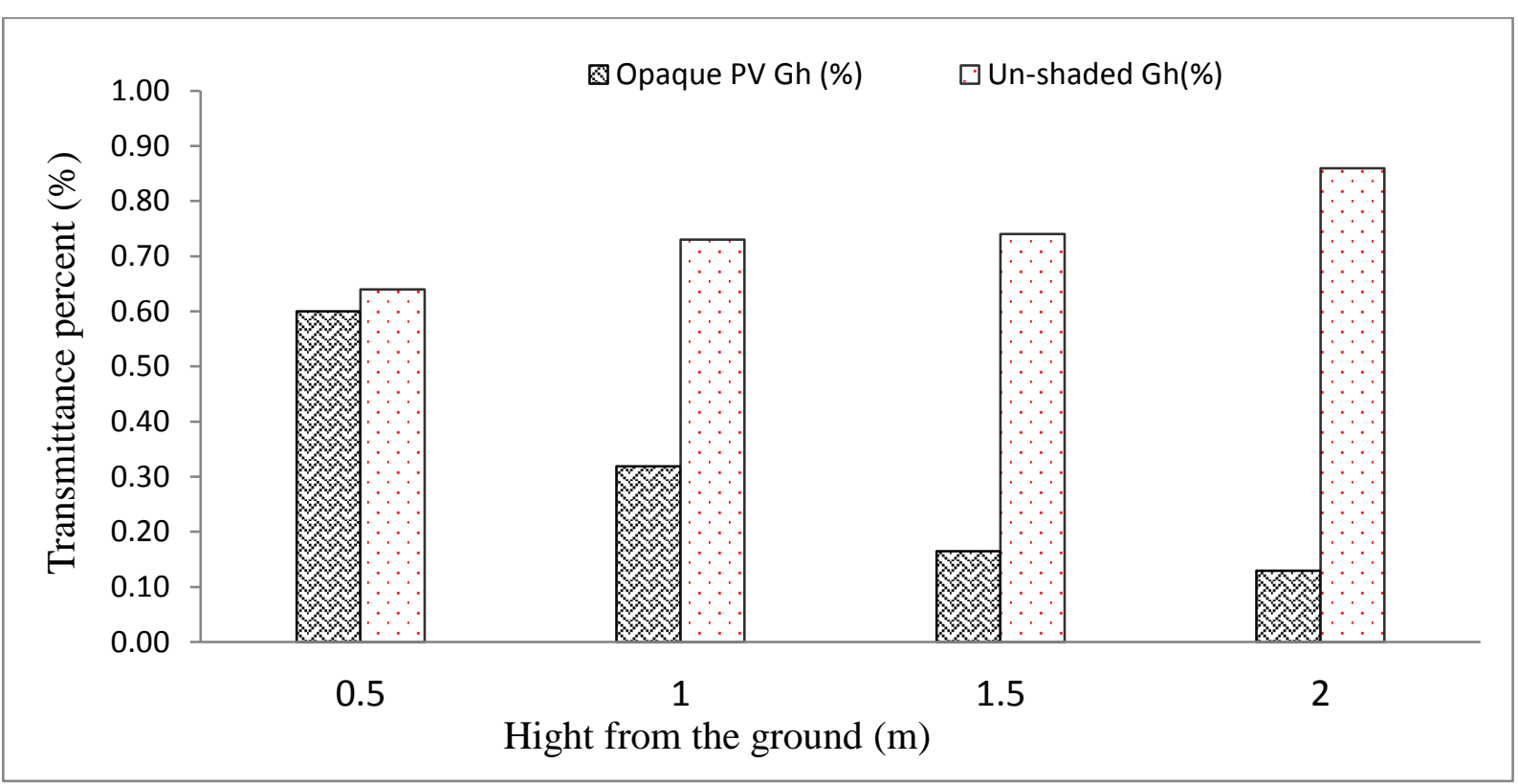

Figure 4: light intensity under different PV panels on $21^{\text {st }}$ of November at 11:00 a.m. 
Subsequently, the light intensity under the un-shaded greenhouse was higher than that of PV at 0.5 to $1 \mathrm{~m}$. Tang et al. (2020) found that the Photosynthetic active radiation was 423 $\mu \mathrm{mol} \cdot \mathrm{m}^{-2} \cdot \mathrm{s}^{-1}$ in the un-shaded side of the same greenhouse and $387 \mu \mathrm{mol} \cdot \mathrm{m}^{-2} \cdot \mathrm{s}^{-1}$ in shaded side by opaque PV in February. These results are similar to the results of Cossu et al. (2017) due to they reported that the yearly a cumulated global radiation increased with the canopy height on the zones under the plastic cover from $59 \%$ at $0.0 \mathrm{~m}$ to $73 \%$ at $2.0 \mathrm{~m}$, and decreased under $50 \%$ PV cover ratio on the roof from $57 \%$ at $0.0 \mathrm{~m}$ to $40 \%$ at $2.0 \mathrm{~m}$.

\subsubsection{Relative humidity}

Relative humidity normally increased at night the maximum was $99 \%$ and decreased during the daytime at 1: 00 p.m. the minimum was $30 \%$ as the air temperatures increased at daytime and decreased during the night, particularly on sunny days and under the natural ventilations as shown in Figure 5. Therefore, as mentioned in the previous paper (Chanchangi et al., 2020) it can be reported that there were no differences in relative humidity in both greenhouses under the opaque PV.

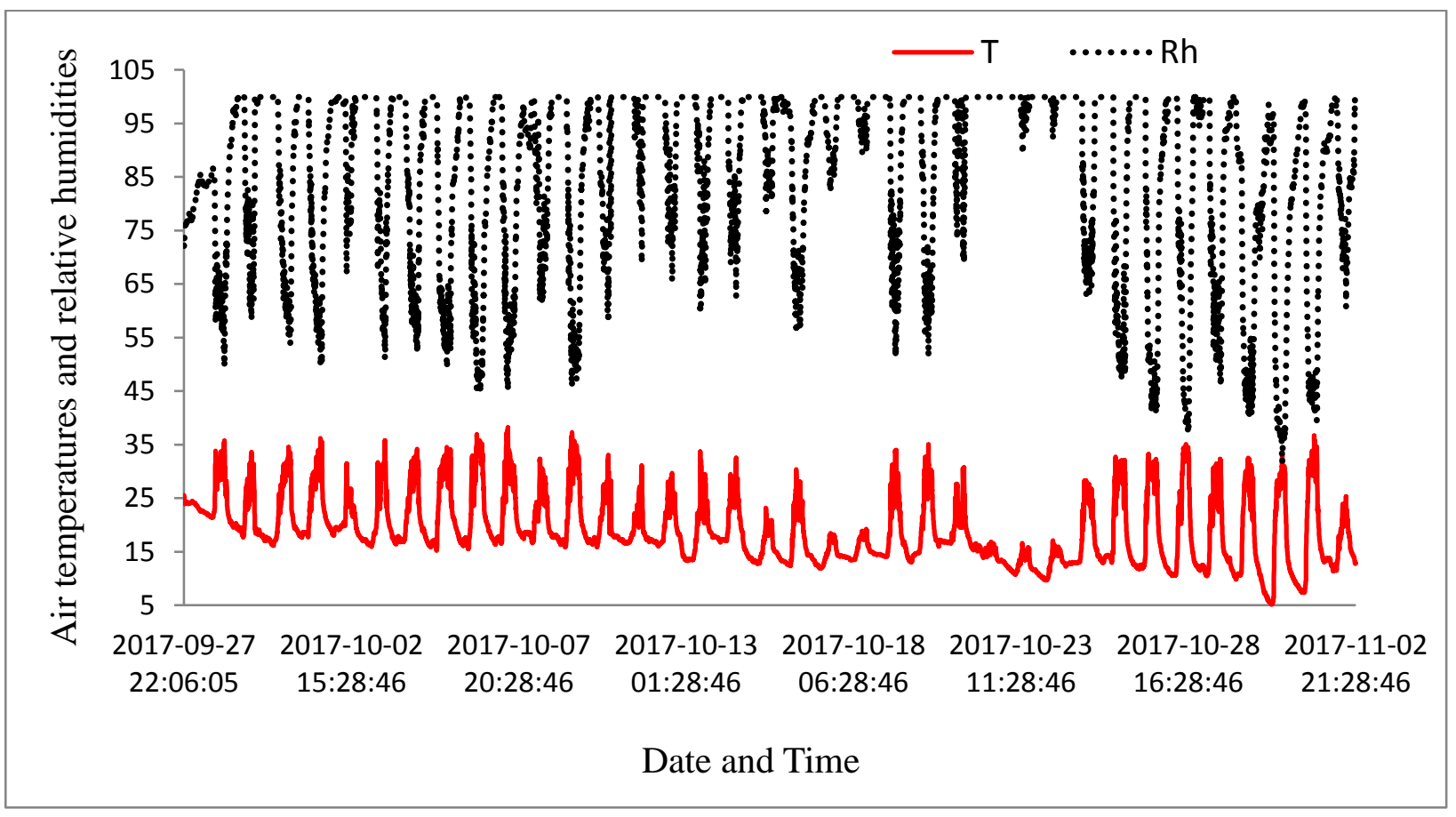

Figure 5: Air temperatures and relative humidifies under the opaque PV greenhouse.

\subsection{PV module temperature}

The flat opaque PV panel's temperatures were higher than that of the ambient temperature in an average of $23.5^{\circ} \mathrm{C}$ during the daytime and there were no more differences at night. The maximum PV temperature for the opaque PV was $47.5{ }^{\circ} \mathrm{C}$ and $24{ }^{\circ} \mathrm{C}$ for the ambient temperature, respectively. The minimum $\mathrm{PV}$ temperature was $5.2{ }^{\circ} \mathrm{C}$ and the minimum ambient temperature was $8{ }^{\circ} \mathrm{C}$. Therefore, the ambient temperature was higher than opaque PV during the night by $2{ }^{\circ} \mathrm{C}$ to $3{ }^{\circ} \mathrm{C}$ because of the heat losses of PV panels at night as shown in Figure 6. These results illustrate that the integration of opaque PV is more suitable to be integrated at a certain distance of the greenhouse roof, hence it cannot cause over heating during the daytime in hot climate regions 


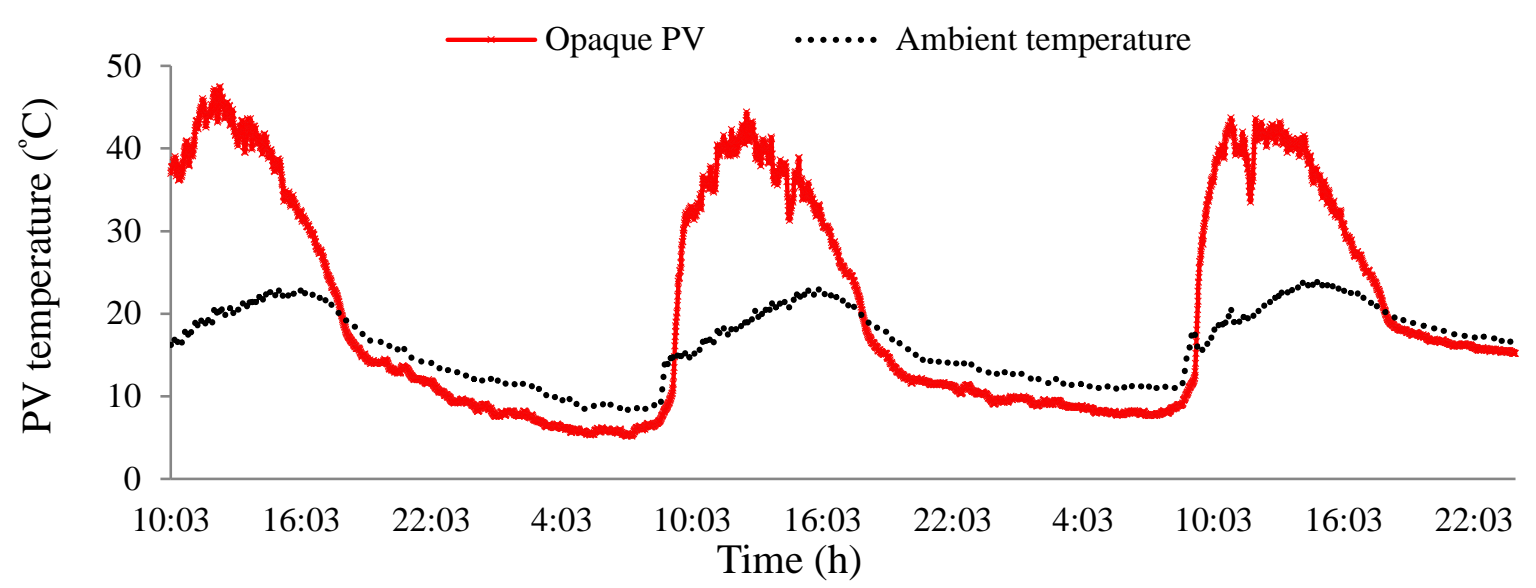

Figure 6: The PV temperatures comparing to the ambient temperature from $14^{\text {th }}$ to $16^{\text {th }}$ November.

\subsection{The generated energy of the PV panels for cooling and heating demands}

The PolySun simulation results revealed that the annual generated energy of the opaque PV panels at a tilt angle of $25^{\circ}$ and roof cover area of $25.9 \%$ facing south is $3195 \mathrm{kWh}(11502$ MJ). Furthermore, the highest generated energy was in March and April and the lowest was in June and July, due to the rainy season starts from June to early October in Kunming as shown in Figure7.

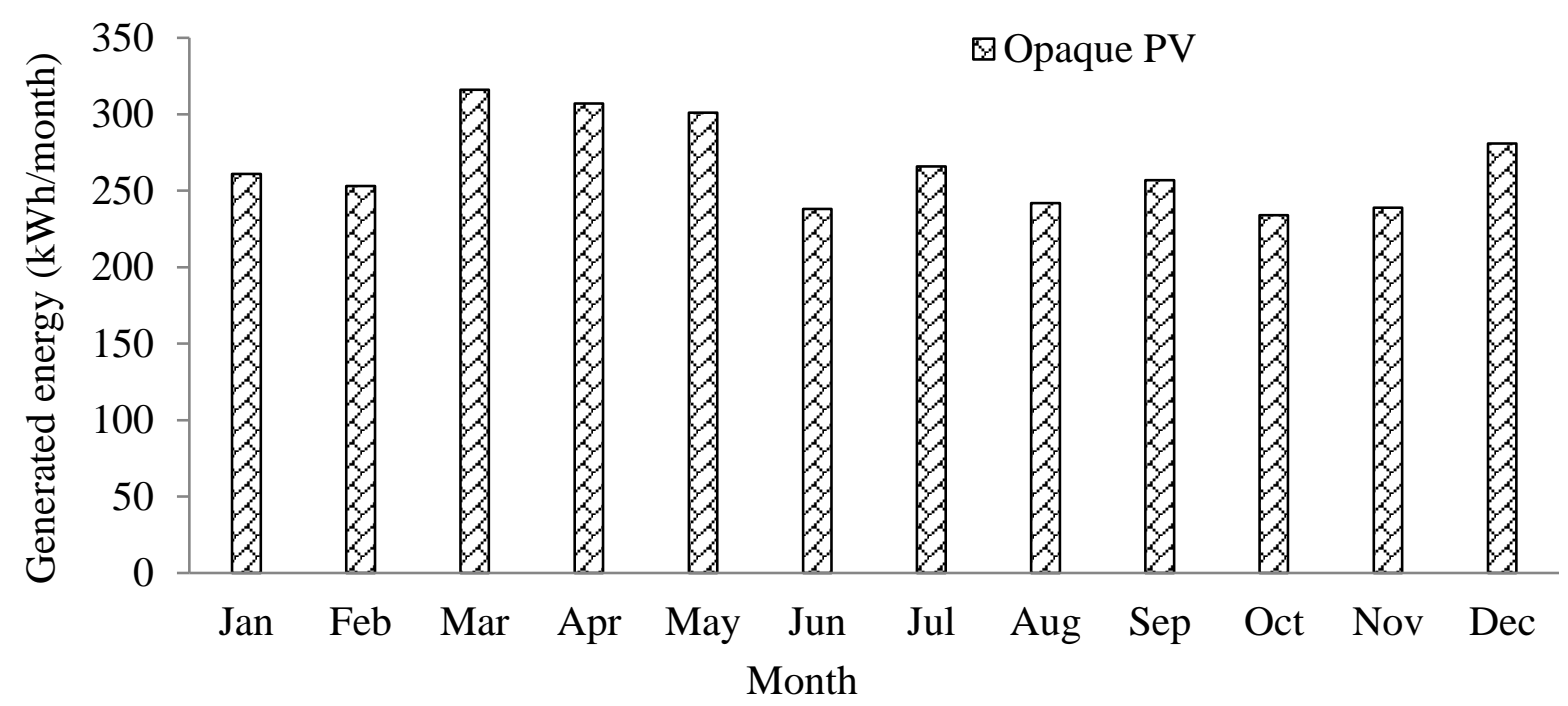

Figure 7: The simulated results of the annual electric energy output of opaque PV solar panels by PolySun program.

The annual electric energy demand for the greenhouse in Kunming can be estimated hence, the greenhouses in Kunming need an auxiliary heating during the Winter season from October to late April, about $5 \mathrm{~h}$ to $10 \mathrm{~h}$ every day and in summer they need about $3 \mathrm{~h}$ for ventilation and air circulation. Results showed that the annual generated energy of the integrated opaque PV panels at $25.9 \%$ of the greenhouse south roof area could cover $30.4 \%$ of the annual energy demand, for the current greenhouse in Kunming. The annual required energy for heating was estimated to be $37864.5 \mathrm{MJ}$ for seven months from October to April at a heating temperature 
set point of $14^{\circ} \mathrm{C}$ (Hasan Ismaeel and Yumrutaş, 2020; Hassanien et al., 2018a). However, the generated energy could be more than enough for the annual cooling demand. Due to the required annual demand for five months of cooling could be only $1170 \mathrm{MJ}$. Therefore, the extra energy in summer could be used to operate the LED lamp or the water pump for a supplemental lighting and irrigation.

\subsection{Effect of different PV panels on the growth of strawberry}

The effect of PV on the growth of strawberry Fragaria ananassa (Jing Zang Xiang) comparing to the un-shaded greenhouse was investigated. It was reported that shading decreased the number of leaves, crowns, and inflorescences as well as reduced the Fruit number(Pérez-Alonso et al., 2012). Temperature and solar radiation are primary environmental factors controlling short-day strawberry plant growth and development

(Babatunde et al., 2018). It was illustrated that shading and salinity reduced the fruit number of strawberry and decreased the fruit dry weight but not fresh weight, which resulted in fruits with higher moisture content (Pérez-Alonso et al., 2012). It was found that exposing strawberry plants to LED for 12 hours (6:00-18:00) daily increased the leaf photosynthetic rates higher than in controls and plants exposed to fluorescent light. These results suggest that supplemental lighting using higher irradiance LED is an effective method for high yield production during forced strawberry cultivation.(Dida et al., 2020).Consequently, the generated energy of PVs could be used to operate the LED lamps as a supplemental lighting at any time of the day, mainly on cloudy days and at night to increase the lighting period.

\subsubsection{Chlorophyll contents}

It can be clearly seen that there was no significant difference on the chlorophyll contents of the shaded plants by opaque PV and the un-shaded strawberry. The average chlorophyll contents of leaves after 60 days were 16.13 SPAD, 16.10 SPAD for the shaded and un-shaded greenhouses respectively. Then, it increased after 70 days of treatments to be 26 SPAD, 25.2 SPAD for the shaded and un-shaded greenhouses, respectively. However, the variation increased after 80 days to be 48 SPAD, 34.5 SPAD for the shaded and un-shaded greenhouses respectively and this variation was higher due to it was measured directly after the fertilizer. Thus, the vegetation of shaded plants was little higher than that of the un-shaded, due to the strawberry preferring the low light intensity (Figure 8).

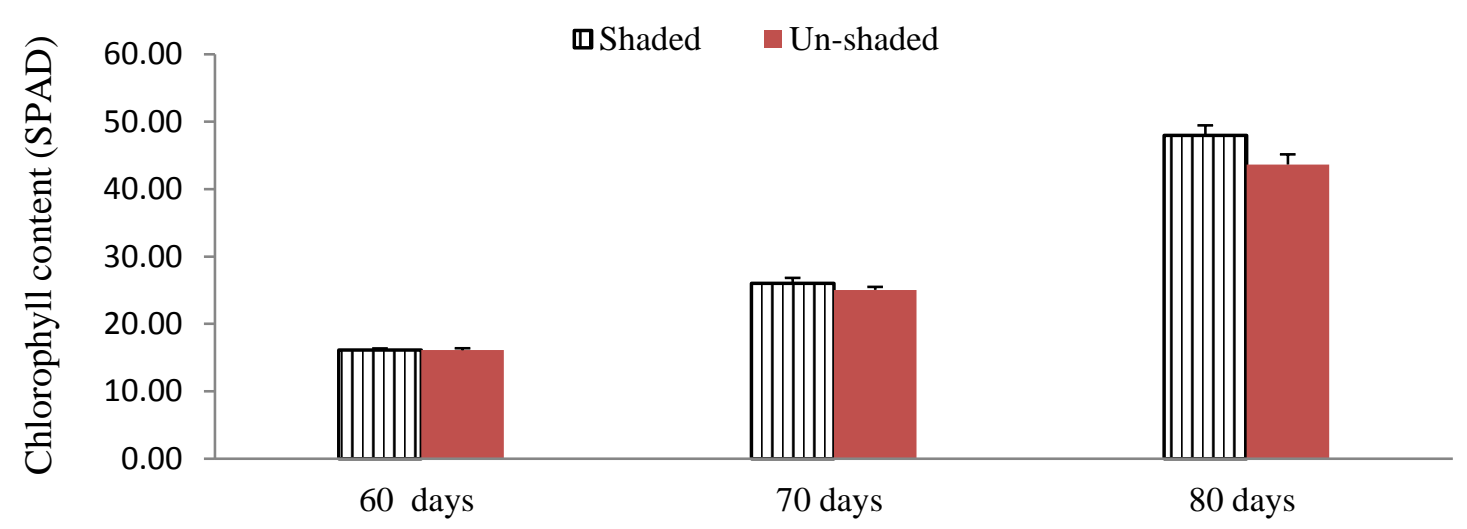

Days after treatments

Figure 8: Chlorophyll contents of strawberry plants. Vertical bars represent mean \pm standard errors at $P<0.05,(\mathrm{n}=20)$ 


\subsubsection{Growth of strawberry}

It was observed that the number of leaves under opaque PV was insignificantly lower than that of the unshaded. The average number of leaves after 40 days of treatments was 9 leaves, 9.3 leaves under shaded and un-shaded greenhouses, respectively. Subsequently, after 70 days the average number was 12 leaves, 13 leaves under shaded and un-shaded greenhouses, respectively as shown in Figure 9A. On the other hand, the number of flowers including fruits under the opaque PV was significantly higher than the number of flowers under the unshaded greenhouses after 30 to 40 days of treatments. Due to the average was 2 flowers under shaded and one flower under un-shaded after 30 days and 4 flowers under shaded and 2 flowers under the un-shaded greenhouse after 40 days. subsequently, the difference was not significant after 55 days of treatments. thus, the fruits under a plastic greenhouse required a longer period of time and late harvest as shown in Figure 9B. It can also observe that, the number of flowers increased under the un-shaded greenhouse after 70 days of treatments due to the early picked fruits under the shaded greenhouse.

A
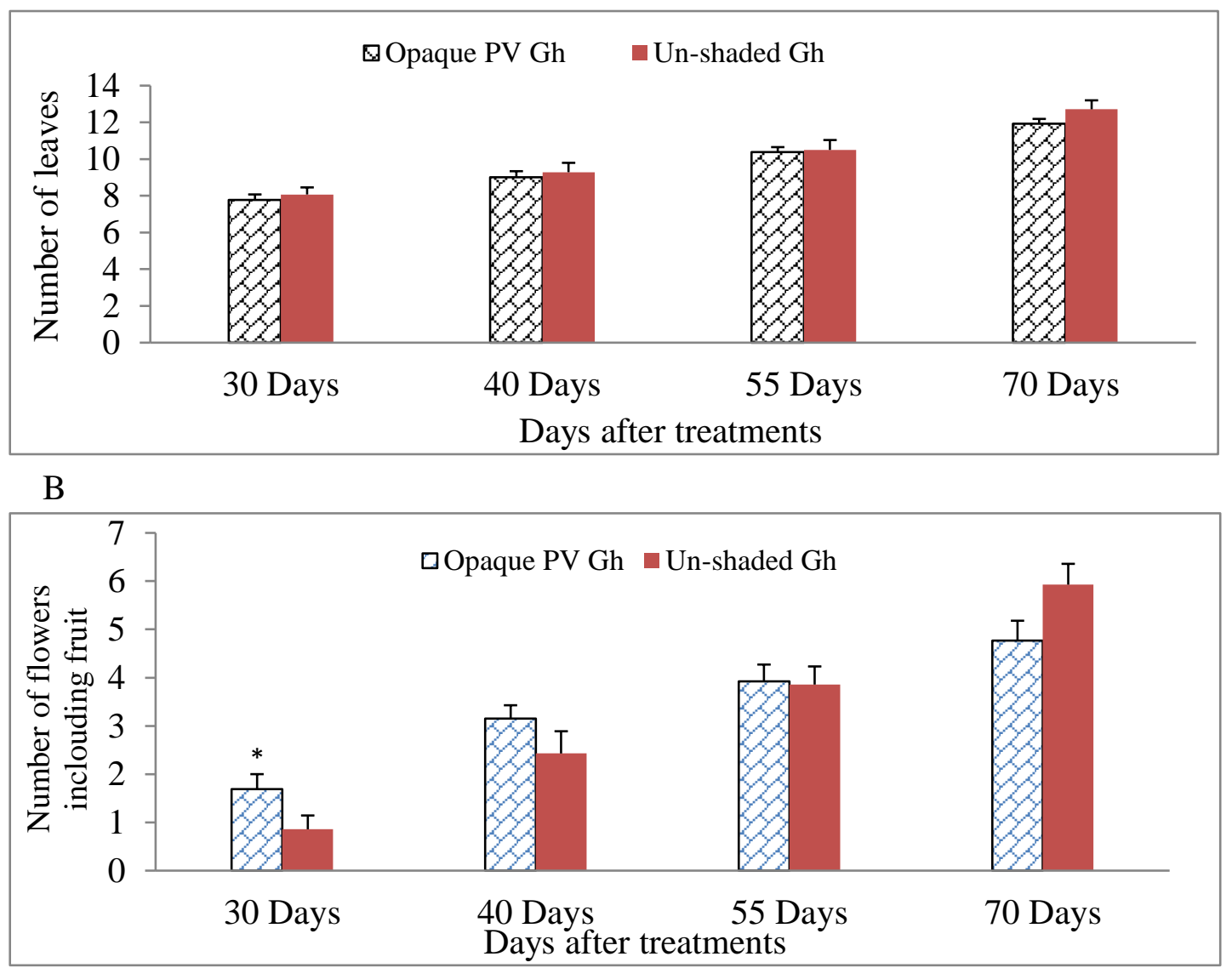

Figure 9: Strawberry growth parameters. (a) Number of leaves for strawberry plants, (b) number of flowers for strawberry plants. Vertical bars represent mean \pm standard errors at $\mathrm{P}<0.05,(\mathrm{n}=12)$

\subsubsection{Strawberry Leaf area}

The average leaf area of the shaded plants by PV was $\left(248 \mathrm{~mm}^{2}\right)$ significantly higher than that of the un-shaded plants $\left(238 \mathrm{~mm}^{2}\right)$, as illustrated in Figure 10. These results in agreement with our previous results of lettuce and tomato (Chanchangi et al., 2020; Thotakura et al., 
2020) due to the plant spontaneously increase its leaf to capture more light. Strawberry plants grown at higher temperatures have smaller leaf size and leaf area.

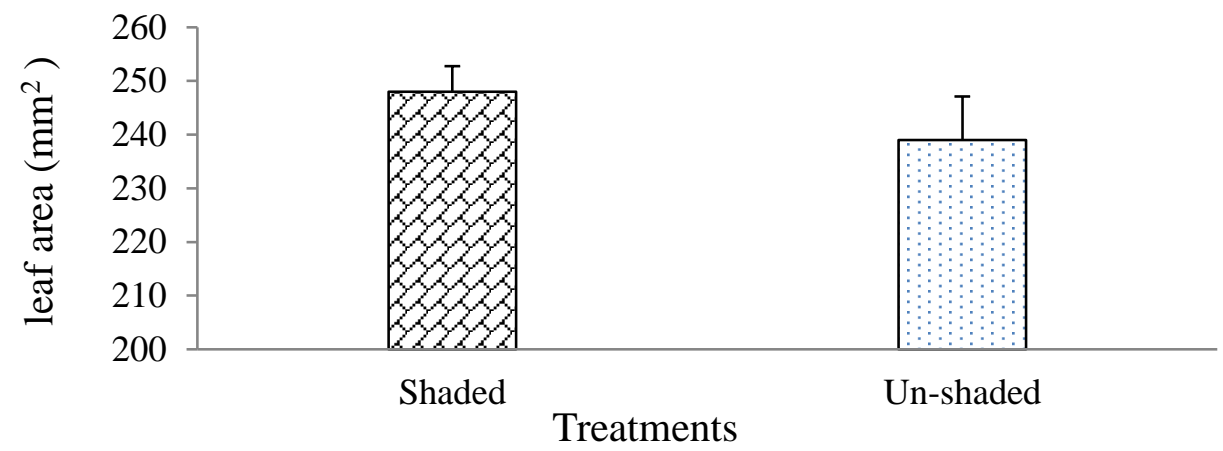

Figure 10: leaf area of strawberry plants. Vertical bars represent mean \pm standard errors at $\mathrm{P}<0.05,(\mathrm{n}=30)$

\section{CONCLUSION}

This experiment has been conducted to investigate the viability of using opaque PV to be integrated with the greenhouse roof for shading purpose and energy production. Meanwhile, it's shading effect on the strawberry growth. It was observed that the shading of opaque PV had no significant influence on the growth of strawberry in terms of leaf area, number of leaves, number of flowers and chlorophyll contents but accelerated the flowering stages. In addition, little differences were observed on the microclimate conditions of both greenhouses (air temperature, relative humidity and solar radiation). Furthermore, the generated energy of opaque PV was more sufficient to cover $30.4 \%$ of the annual energy demand. Therefore, it can be highly recommended for shading the strawberry plants in greenhouses by the opaque $\mathrm{PV}$ at the South roof as long as the panel distributed at a distance on the roof to allow more light to enter the greenhouse.

\section{REFERENCES}

Ahemd H.A., Al-Faraj A.A., Abdel-Ghany A.M. (2016) 'Shading greenhouses to improve the microclimate, energy and water saving in hot regions: A review'. Sci Hortic-Amsterdam 201:36-45. DOI: http://dx.doi.org/10.1016/j.scienta.2016.01.030.

Al-Ibrahim A., Al-Abbadi N, Al-Helal I. (2006)' PV greenhouse system, system description, performance and lesson learned'. Acta Hortic (ISHS) 710:251-264.

Al-Rousan N., Isa N.A.M., Desa M.K.M. (2018) 'Advances in solar photovoltaic tracking systems: A review'. Renew Sustain Energy Rev. 82:2548-2569. DOI: https://doi.org/10.1016/j.rser.2017.09.077.

Al-Shamiry F., et al. (2007) 'Design and development of photovoltaic power system for tropical greenhouse cooling'. Am J Appl Sci 4:386-389.

Babatunde A.A., Abbasoglu S., Senol M. (2018) 'Analysis of the impact of dust, tilt angle and orientation on performance of PV Plants'. Renew Sustain Energy Rev.90:1017-1026. DOI: https://doi.org/10.1016/j.rser.2018.03.102.

Breyer C., Koskinen O., Blechinger P. (2015) 'Profitable climate change mitigation: The case of greenhouse gas emission reduction benefits enabled by solar photovoltaic systems'. Renew Sustain Energy Rev 49:610-628. DOI: http://dx.doi.org/10.1016/j.rser.20.15.04.061. 
Chanchangi Y.N., et al. (2020) 'Dust and PV Performance in Nigeria: A review'. Renew Sustain Energy Rev. 121:109704. DOI: https://doi.org/10.1016/j.rser.2020.109704.

Cossu M., et al. (2017) 'An algorithm for the calculation of the light distribution in photovoltaic greenhouses'. Solar Energy 141:38-48. DOI: http://dx.doi.org/10.1016/j.solener.2016.11.024.

Cossu M., et al. (2014) 'Solar radiation distribution inside a greenhouse with south-oriented photovoltaic roofs and effects on crop productivity'. Appl Energ 133:89-100. DOI: http://dx.doi.org/10.1016/j.apenergy.2014.07.070.

Dida M., et al. (2020) 'Output power loss of crystalline silicon photovoltaic modules due to dust accumulation in Saharan environment'. Renew Sustain Energy Rev. 124:109787. DOI: https://doi.org/10.1016/j.rser.202.0.109787.

Ghoulem M., et al.(2019) 'Greenhouse design and cooling technologies for sustainable food cultivation in hot climates: Review of current practice and future status'. Biosystems Engineering 183.121- 150. DOI: https://doi.org/10.1016/j.biosystemseng.2019.04.016.

Giampieri F., et al. (2012) 'The strawberry: Composition, nutritional quality, and impact on human health'. Nutrition 28:9-19 .DOI: http://dx.doi.org/10.1016/j.nut.2011.08.009.

Hasan Ismaeel H., Yumrutaş R. (2020) 'Investigation of a solar assisted heat pump wheat drying system with underground thermal energy storage tank'. Solar Energy 199:538551. DOI: https://doi.org/10.1016/j.solener.2020.02.022.

Hassanien R.H.E., Li M., Dong Lin W. (2016) 'Advanced applications of solar energy in agricultural greenhouses'. Renew Sustain Energy Rev. 54:989-1001. DOI: http://dx.doi.org/10.1016/j.rser.2015.10.095.

Hassanien R.H.E., Li M., Tang Y. (2018a) 'The evacuated tube solar collector assisted heat pump for heating greenhouses'. Energy and Buildings 169:305-318. DOI: 10.1016/j.enbuild.2018.03.072.

Hassanien R.H.E., Li M., Yin F. (2018b) 'The integration of semi-transparent photovoltaics on greenhouse roof for energy and plant production'. Renewable Energy 121:377-388. DOI: 10.1016/j.renene.2018.01.044.

Kadowaki M., et al. (2012) 'Effects of greenhouse photovoltaic array shading on Welsh onion growth'. Biosyst Eng 111. 290-297. DOI: http://dx.doi.org/10.1016/j.biosystemseng.2011.12.006.

Khanlari A., et al. (2020) 'Performance enhancement of a greenhouse dryer: Analysis of a cost-effective alternative solar air heater'. Journal of Cleaner Production 251:119672. DOI: https://doi.org/10.1016/j.jclepro.2019.119672.

Ledesma N.A., Kawabata S. (2016) 'Responses of two strawberry cultivars to severe high temperature stress at different flower development stages'. Scientia Horticulturae 211:319-327. DOI: http://dx.doi.org/10.1016/j.scienta.2016.09.007.

Li C., et al. (2017) 'The economic and social performance of integrated photovoltaic and agricultural greenhouses systems: Case study in China'. Appl Energy 190:204-212. DOI: http//:dx.doi.org/10.1016/j.apenergy.2016.12.121. 
Marrou H., Dufour L., Wery J. (2013) 'How does a shelter of solar panels influence water flows in a soil crop system?' Eur $J$ Agron 50:38-51. DOI: http://dx.doi.org/10.1016/j.eja.2013.05.004.

Paul W. Stackhouse J (2015). NASA Surface meteorology and Solar Energy.

Pérez-Alonso J., et al. (2012) 'Performance analysis and neural modelling of a greenhouse integrated photovoltaic system'. Renew Sustain Energy Rev. 16:4675-4685. DOI: https://doi.org/10.1016/j.rser.2012.04.002.

Raúl U.S., et al. (2012) 'Greenhouse tomato production with electricity generation by roofmounted flexible solar panels' .Sci Agr 69:233-239.

Reca J., et al. (2016) 'Feasibility analysis of a standalone direct pumping photovoltaic system for irrigation in Mediterranean greenhouses'. Renewable Energy 85:1143-1154. DOI: https://doi.org/10.1016/j.renene.2015.07.056.

Rylski I., Spigelman M. (1986) 'Effect of shading on plant development, yield and fruit quality of sweet pepper grown under conditions of high temperature and radlation'. Scientia Horticulturae 29:31-35. DOI: https://doi.org/10.1016/03.2-90028(86)4238-04.

Sivakumar D., Jifon J. (2018) Chapter 5 - Influence of Photoselective Shade Nettings on Postharvest Quality of Vegetables, in: M. W. Siddiqui (Ed.), Preharvest Modulation of Postharvest Fruit and Vegetable Quality, Academic Press. pp. 121-138.

Sonneveld P.J., et al. (2010) 'Performance results of a solar greenhouse combining electrical and thermal energy production'. Biosy Eng 106:48-57. DOI: http://dx.doi.org/10.1016/j.biosystemseng.2010.02.003.

Tang Y., et al. (2020) 'The effect of temperature and light on strawberry production in a solar greenhouse'. Solar Energy 195:318-328. DOI: https://doi.org/10.1016/j.solener.2019.11.070.

Thotakura S., et al. (2020) 'Operational performance of megawatt-scale grid integrated rooftop solar PV system in tropical wet and dry climates of India'. Case Studies in Thermal Engineering 18:100602. DOI :https://doi.org/10.1016/j.csite.2020.100602.

Trypanagnostopoulos G., et al. (2017) 'Greenhouse performance results for roof installed photovoltaics'. Renew Energy 111:724-731. DOI: https://doi.org/10.1016/j.renene.201.7.04.066.

Waller R., et al. (2021) 'Semi-Transparent Organic Photovoltaics Applied as Greenhouse Shade for Spring and Summer Tomato Production in Arid Climate'. Agronomy 11:1152.

Yano A., et al. (2009) Electrical energy generated by photovoltaic modules mounted inside the roof of a north-south oriented greenhouse. Biosyst Eng (103):228-238. DOI: http://dx.doi.org/10.1016/j.biosystemseng.2009.02.020.

Yano A., et al. (2010) 'Shading and electrical features of a photovoltaic array mounted inside the roof of an east-west oriented greenhouse'. Biosyst Eng (106):367-377. DOI: http://dx.doi.org/10.1016/j.biosystemseng.2010.04.007.

Yano A., Onoe M., Nakata J. (2014) 'Prototype semi-transparent photovoltaic modules for greenhouse roof applications'. Biosyst Eng (122):62-73. DOI: http://dx.doi.org/10.1016/j.biosystemseng.2014.04.003. 
تأثير التظليل بالخلايا الكهروضوئية على نمو الفراولة والمناخ الدقيق داخل الصوبات الزراعية

رضا حسانين امام حسانين' و منج لي' لئ

' استاذ الهندسة الزر اعية المساعد ـ كلية الزر اعة ـ جامعة القاهرة ـ مصر.

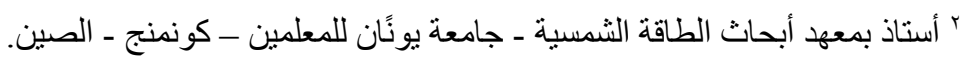

\section{الملخص العربي}

ناقتت هذه الدراسة تأثثير استخدام الخلايا الكهروضوئية المعتمة عند استخدامها دائا

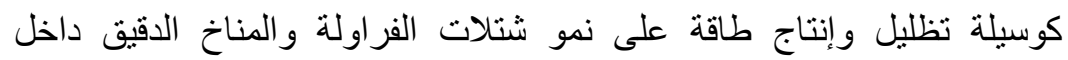

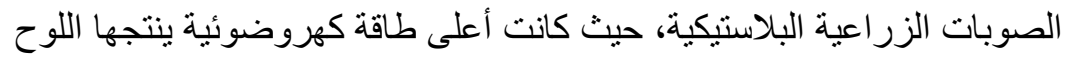

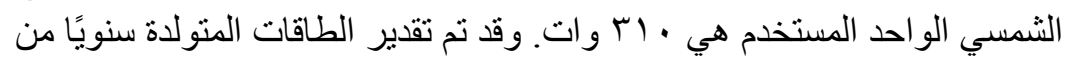

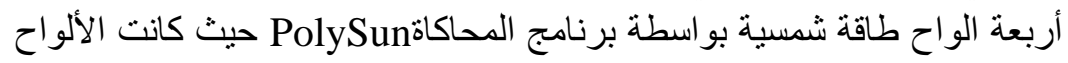

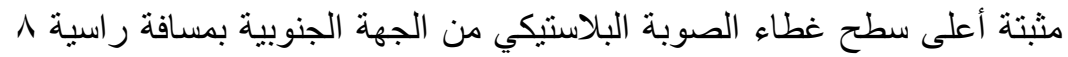

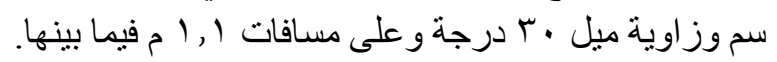

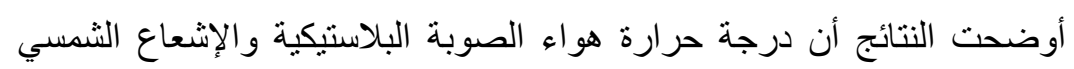

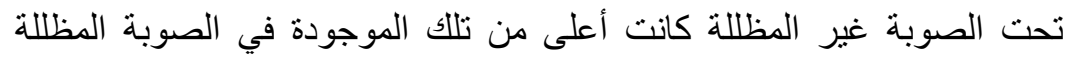

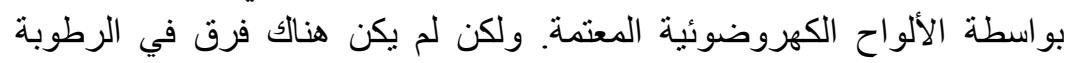

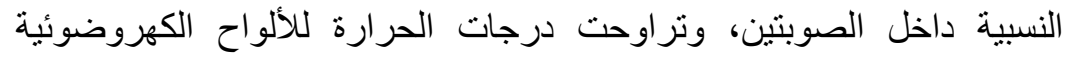

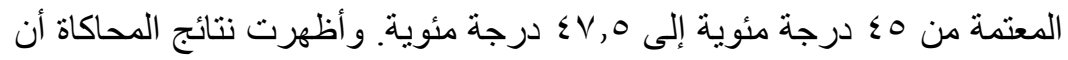

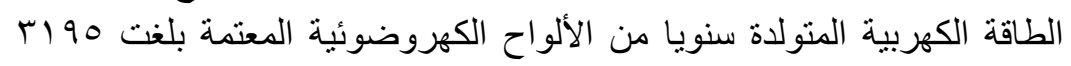

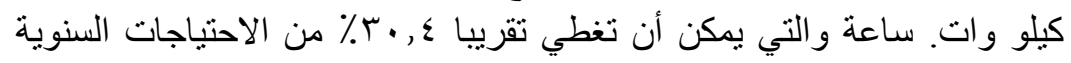

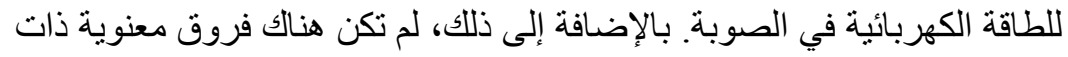

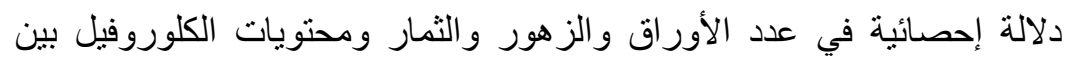

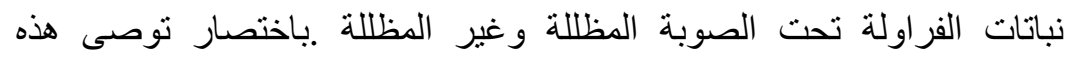

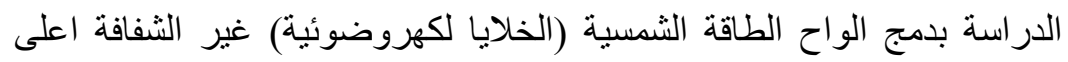

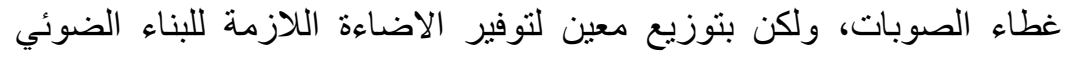

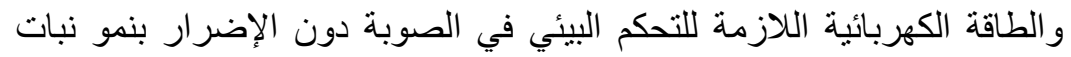
الفراولة.

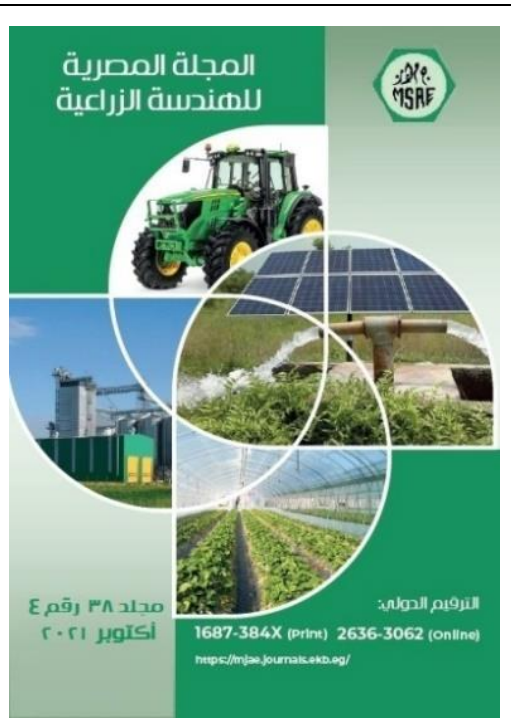

(C) المجلة المصرية للهنسة الزراعية

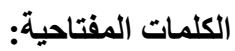

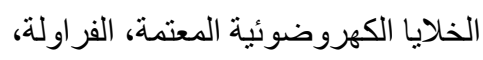
التظليل، النمو، الإثعاع الثمسي، درجة الثنة الثراءة

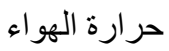

